\title{
From in vitro research to real life studies: an extensive narrative review of the effects of balneotherapy on human immune response
}

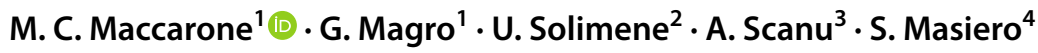

Received: 17 November 2020 / Accepted: 4 May 2021 / Published online: 20 May 2021

(c) The Author(s) 2021

\begin{abstract}
Purpose The biologic mechanisms by which balneotherapy (BT) alleviates symptoms of different diseases are still poorly understood. Recently, preclinical models and clinical trials have been developed to study the effects of BT on the immune system. This review summarizes the currently available evidence regarding the effects of spa therapy on the immune response, to confirm the role of BT in the enhancement of immune system and open interesting research fields.

Methods PubMed and Google Scholar were searched from 1997 up to June 2020, with search criteria including terms related to BT and immune system. We selected only in vitro research, randomized controlled trials (RCTs) or clinical trials. Results In vitro studies on human and animal samples have demonstrated that thermal waters exert anti-inflammatory and immunomodulatory effects. In particular, $\mathrm{H}_{2} \mathrm{~S}$ donors seem to counteract the inflammatory processes in psoriatic lesions, arthritic fibroblast-like synoviocytes and chondrocytes, and regulate important factors implicated in osteoarthritis pathogenesis and progression. RCTs and clinical trials revealed, after BT, a reduction in circulating levels of pro-inflammatory molecules, such as TNF- $\alpha$, IL-1 $\beta$, and C-reactive protein, and an increase in anti-inflammatory molecules such as the IGF-1 growth factor especially in musculoskeletal diseases.
\end{abstract}

Conclusion Further preclinical studies and RCTs could help to exploit BT in real life for preventive and therapeutic treatments.

Keywords Spa therapy $\cdot$ Health resort therapy $\cdot$ Mud therapy $\cdot$ Peloidotherapy $\cdot$ Immune system

\section{Introduction}

In the era of COVID-19 pandemic, the importance of the immune system has become central, becoming a topic of great interest in several fields of medicine. It is interesting to know whether health resort therapy, one of the most commonly used complementary therapies, especially as mud and baths applications, can affect the immune system. In recent years, there has been an increased interest in the use of preclinical models (in vitro studies on human or

M. C. Maccarone

mariachiara.maccarone93@gmail.com

1 Physical Medicine and Rehabilitation School, University of Padova, Via Giustiniani 3, 35128 Padua, Italy

2 World Federation of Hydrotherapy and Climatotherapy, Milan, Italy

3 Reumathology Unit, Department of Medicine - DIMED, University of Padova, Padua, Italy

4 Rehabilitation Unit, Department of Neuroscience, University of Padova, Padua, Italy animal samples) to investigate the biological effects of balneotherapy (BT) on inflammation and immunity. Recently, also clinical trials and Randomized Controlled Trials (RCTs) have been developed to study the effects of BT on the human immune system.

BT includes immersion in thermal waters, balneological interventions with natural gases, mud applications and other traditional remedies [1]. The treatment in the spa setting is frequently supplemented by other interventions including health education and health promotion strategies [2]. Many mineral-rich waters have been confirmed to have effects on the immune system and recent findings suggest that BT and mud therapy may act on the immune response even if the mechanisms are still not completely understood $[3,4]$. Our aim is to summarize the current available information about the effects of thermal mineral waters or of their organic and inorganic components on the immune response not only to confirm the important role of BT in the enhancement of human immune system but also to open interesting further fields of research. 


\section{Materials and methods}

A scoping review was conducted with the aim of searching for the evidence of BT effects on the immune responses and the immune system from 1997. First, the research question was defined by the first author in collaboration with the other authors. Then, a bibliographic research was carried on Medline (PubMed) and Google Scholar. As keywords, we used spa therapy, health resort medicine, balneotherapy, mud therapy, immune response, immunity, immune system combined employing the Boolean operators. Studies were eligible if they were in vitro research on human or animal samples, randomized controlled trials (RCTs) or clinical trials; BT or mineral-rich water or mud applications had to be the intervention under study and had to be compared with another intervention or with no intervention. A comprehensive process of identifying and selecting appropriate studies was conducted.

Studies selected for the review needed to have the abstract available and published in English. Articles with the abstract written in languages other than English were excluded.

All original research articles published from 1997 up to June 2020 were analyzed.

Case reports, letters to the editor, and studies published before 1997 were excluded. Also repetitions and studies not related to the topic were excluded.

At the end of the selection process, 40 studies were elegible for the scoping review.

After the identification of relevant studies, the data were extracted and charted. Papers that did not meet the inclusion criteria were excluded. The first author and his assistants independently screened the papers and downloaded the full-text versions. The authors' names, the year of publication, the journal, the pathology investigated, the study design or the experimental model, the population, the age of the participants, the kind of water/mud utilized, the presence of a comparison group, the outcomes evaluated, and the significance of the results were extracted and gathered in comprehensive tables.

\section{Results}

\section{In vitro studies on human samples evaluating the beneficial effects of BT on immune response in skin diseases}

Most of the in vitro studies on human samples evaluating the immunological effects of thermal waters in dermatology focused on psoriasis. Psoriasis is an immune-mediated, inflammatory disease, in which intralesional $\mathrm{T}$ lymphocytes induce keratinocytes to proliferate and perpetuate the disease process. The interleukins IL-17 and IL-22 produced by Th1/Th17 lymphocytes stimulate IL-8 secretion by keratinocytes, and this represents a key event in the psoriasis pathogenesis [5]. Sulfur is able to penetrate the skin, and sulfur-rich waters used in BT may be effective in the treatment of psoriasis. Evaluating the effects of thermal water rich in sodium hydrosulfide (NaHS) on human psoriatic keratinocytes, Gobbi et al. [6] and Mirandola et al. [7] demonstrated a reduction in psoriasis lesions through a decrease in IL-8, IL-17 and IL-22.

Since skin psoriatic manifestations are thought to be angiogenesis-dependent, effects on the expression and release of vascular endothelial growth factor (VEGF)-A were studied by Chiarini et al. [8] using Comano's thermal water, rich in sodium, calcium and bicarbonate. They demonstrated, evaluating cultured human lesional keratinocytes exposed to thermal water, that BT interferes with VEGF-A expression and secretion. Also, a reduction in IL-6 levels and in the expression of cytokeratin-16, a marker associated with keratinocyte psoriatic phenotype, was demonstrated [9]. Finally, a reduction in the intracellular and secretion levels of IL-8 and tumor necrosis factor (TNF)- $\alpha$, pro-inflammatory cytokines overexpressed in psoriatic lesions, was shown using the same water [10].

Karagülle et al. in 2018 [11], evaluating human psoriasis and rosacea keratinocytes treated with Bursa and Bolu thermal mineral waters showed a reduction of inflammation and neo-angiogenic phenomena (reduced IL- $1 \alpha$, TNF- $\alpha$, and VEGF gene expression).

Lee et al. [12] evaluated the effects of thermal water on human keratinocytes related to skin immune reactions. The treatment with thermal water decreased the expression of pro-inflammatory cytokines, such as IL-6, IL-8, IL- $1 \alpha$, TNF- $\alpha$, and granulocyte-macrophage colony-stimulating factor (GM-CSF). In addition, the differentiation process of subsets of T helper cells, such as Th1, Th2 and Th17 cells (related to autoimmunity or to inflammatory skin diseases), was reduced. Thermal water induced also Foxp $3^{+} \mathrm{T}_{\text {reg }}$ cell differentiation in vitro, implying that the immunomodulatory effect also includes $\mathrm{T}_{\text {reg }}$ cell-induced immune suppressive effects.

All the treatment details and the results of these studies are reported in Table 1.

\section{In vitro studies on human samples evaluating the beneficial effects of BT on immune response in musculoskeletal diseases}

Immunological effects of BT in musculoskeletal diseases have been most widely studied in rheumatic disorders. Fox et al. [13] studied the ability of human primary chondrocytes 


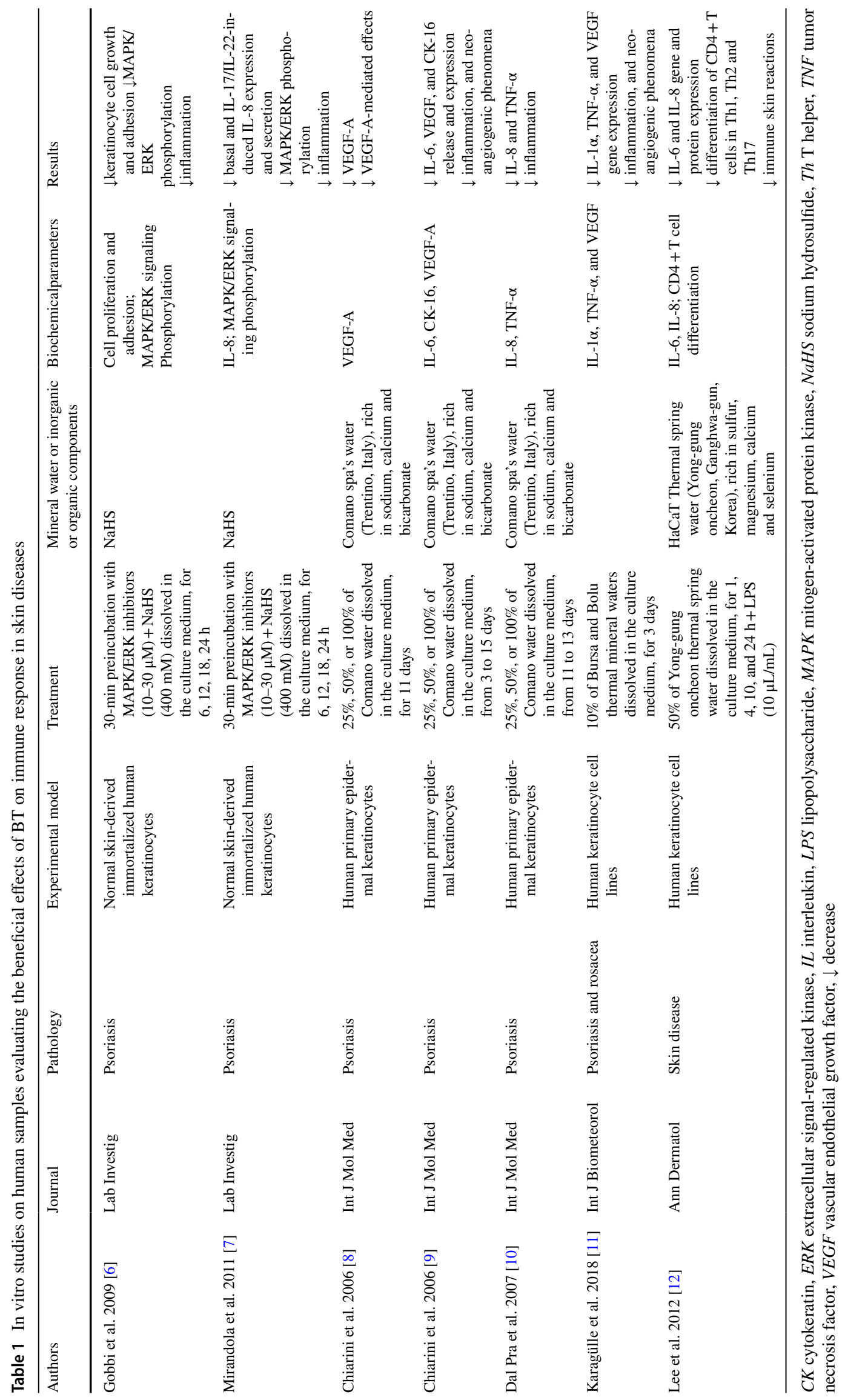


and mesenchymal progenitor cells to synthesize hydrogen sulfide $\left(\mathrm{H}_{2} \mathrm{~S}\right)$ in response to pro-inflammatory stimulation and their response to an exogenous slow-releasing $\mathrm{H}_{2} \mathrm{~S}$ source, the morpholin-4-ium 4 methoxyphenyl (morpholino) phosphinodithioate (GYY4137). Endogenous $\mathrm{H}_{2} \mathrm{~S}$ produced by the cells and the treatment with GYY4137 significantly reduced cell death and oxidant-induced mitochondrial dysfunction, caused by inflammatory cytokines.

Li et al. [14] assessed the effect of GYY4137 on lipopolysaccharide (LPS)-dependent release of inflammatory mediators from human arthritis synoviocytes and articular chondrocytes. GYY4137 demonstrated an anti-inflammatory effect decreasing the production of nitrite, prostaglandin E2 (PGE2), TNF- $\alpha$, and IL-6 from both cell types, reducing the levels and the catalytic activity of inducible nitric oxide synthase (iNOS) and cyclooxygenase (COX)-2, and nuclear factor kappa B (NF-kB) activation induced by LPS. Similar results were obtained by Burguera et al. [15] Ha et al. [16] in studies on human osteoarthritis (OA) chondrocytes stimulated with IL- $1 \beta$, a pro-inflammatory cytokine, to reproduce the "OA-like effect". Burguera et al.'s study was also the first to demonstrate the anti-catabolic activity of these compounds through the downregulation of metalloproteinase (MMP)-13. Also, Fioravanti et al. [17] studying the potential beneficial effect of Vetriolo thermal water (Trentino Alto Adige, Italy), a highly mineralized water, strongly acidic sulfate, rich in calcium, magnesium, and iron, in human OA chondrocytes, showed after the treatment a significant reduction in NO levels and in the expression of iNOS.

Sieghart et al. [18] showed that the NaHS treatment in OA fibroblast-like synoviocytes reduced spontaneous and IL-1 $\beta$-induced secretion of IL-6, IL-8, the expression of MMP-2 and MMP-14, and the phosphorylation of several mitogen-activated protein kinases (MAPKs). Later, a similar research was conducted on OA cartilage extracts co-cultured with IL-1 $\beta$ and NaHS or GYY4137 [19]. At the end of the treatment, there was a reduction of the catabolic processes (decrease in glycosaminoglycan destruction and MMP-3 and MMP-13 production) and a stimulation of the cell anabolism (increased synthesis of collagen type II alpha 1 chain and aggrecans).

Kloesch et al. [20, 21] evaluated the effects of NaHS on fibroblast-like synoviocytes derived from rheumatoid arthritis (RA) and OA patients. IL-1 $\beta$-induced expression of IL-6 was transiently and partially down-regulated with low concentrations of $\mathrm{NaHS}$. Long-term exposure to $\mathrm{H}_{2} \mathrm{~S}$ and high concentration of NaHS provided stimulatory effects, leading to the reinforced activation of p38 MAPK and extracellular signal-regulated kinases (ERK)1/2 accompanied by upregulation of IL-6 expression. In 2012, Kloesch et al. [22] demonstrate a reduction of IL-6 and IL-8 expression and the activation of $\mathrm{p} 38 / \mathrm{MAPK} / \mathrm{ERK}$ and NF-kB signaling in a human chondrocyte cell line treated with NaHS.
On bone-derived cells, only a limited number of in vitro studies were performed. On human osteoclasts, after an incubation period with NaHS, a significant decrease in osteoclast differentiation and intracellular reactive oxygen species (ROS) levels, and an increased transcription of antioxidant genes were observed [23].

All the treatement details and the results of these studies are reported in Table 2.

\section{In vitro studies on animal samples evaluating the beneficial effects of BT on immune response in musculoskeletal diseases}

Xu et al. [24] showed the proliferative, antioxidant, and antiinflammatory effects of a treatment with NaHS in hydrogen peroxide-stimulated murine osteoblast-like cell line. The antioxidant effects were confirmed by Lv et al. [25], in an analogous experimental study, examining the effect of GYY4137 added at the culture medium for $4 \mathrm{~h}$ in the presence of hydrogen peroxide $\left(\mathrm{H}_{2} \mathrm{O}_{2}\right)$.

On rat primary osteoblasts cultured with NaHS, after an incubation with high glucose concentration, NaHS significantly prevented osteoblast injury induced by glucose, blocking the glucose-induced osteoblast mineralization inhibition [26].

All the treatment details and the results of these studies are reported in Table 3.

\section{In vitro studies on human samples evaluating the beneficial effects of BT on immune response in inflammatory diseases}

The protective effects of $\mathrm{H}_{2} \mathrm{~S}$ and of its exogenous sources on cellular immune response were first investigated by Rinaldi et al. [27] in a study on purified human neutrophils, eosinophils, and lymphocytes of human donors treated with NaHS at different concentrations for $24 \mathrm{~h}$. After the treatment, an increased short-term survival of neutrophils was found, while no changes in lymphocytes and eosinophils were observed. A similar experimental protocol was performed by Mirandola et al. [28] in peripheral blood lymphocytes purified from healthy subjects. After the incubation with NaHS, a decreased proliferation of $\mathrm{CD} 8+\mathrm{T}$ and natural killer (NK) cells and reduced IL-2 production were observed. Sulen et al. [29] stimulated human peripheral blood mononuclear cells with NaHS, showing after the treatment the phosphorylation of $\mathrm{p} 38$, protein kinase $\mathrm{B}$ (Akt), and cAMP-response element-binding protein (CREB).

The proliferative activity of $\mathrm{H}_{2} \mathrm{~S}$ donors was also demonstrated in a study carried out on peripheral blood lymphocytes isolated from patients with systemic lupus erythematosus. $\mathrm{H}_{2} \mathrm{~S}$ donors inhibited the abnormal activation and 
proliferation of lupus lymphocytes through the Akt/glycogen synthase kinase 3 beta (GSK3 $\beta$ ) pathway [30].

In activated human neutrophils treated with sulfurous water of Acqui Terme (Piemonte, Italy), a significant reduction of ROS and reactive nitrogen species (RNS) was observed after the treatment [31]. A similar experiment conducted treating neutrophils with different concentrations of the above mentioned sulfurous water or NaHS demonstrated the inhibition of elastase release, revealing a possible contribution in controlling the inflammatory processes of airway diseases [32].

In human primary monocytes treated with NaHS, the production of TNF- $\alpha$, IL-1 $\beta$, IL-6, IL-12, and C-C motif chemokine ligand 5 (CCL5) induced by LPS was blocked and ROS formation and antioxidant enzymes activity were reduced. Sirmione thermal water (Lombardia, Italy), rich in sodium chloride, bromide, and iodide, did not show the same results, and enhanced the release of IL-10, probably due to the low concentration of sulfur compounds [33].

Given the important role of Th17/Treg cell ratio in the onset and evolution of immune-mediated pathologies, in 2018, Vitale [34] investigated the effects of exogenous $\mathrm{H}_{2} \mathrm{~S}$ on human CD4 $\mathrm{T}$ cell polarization to Th17 and/or Treg phenotype. NaHS treatment increased both Foxp3 mRNA levels in $\mathrm{CD} 4+\mathrm{T}$ cells under Treg-polarizing conditions and retinoic acid-related orphan receptor gamma $(\mathrm{ROR} \gamma \mathrm{T}) \mathrm{mRNA}$ levels in CD $4+\mathrm{T}$ cells under Th17 polarizing conditions, suggesting a role of sulfur in both polarization pathways.

All the treatment details and the results of these studies are reported in Table 4.

\section{In vitro studies on animal samples evaluating the beneficial effects of BT on immune response in inflammatory diseases}

$\mathrm{H} 2 \mathrm{~S}$ can have a role also as an endogenous and exogenous immunomodulatory molecule in $\mathrm{T}$ cells signal in inflammatory bowel diseases. $\mathrm{H}_{2} \mathrm{~S}$ donors employed to treat primary mouse $\mathrm{T}$ lymphocytes $(\mathrm{CD} 3+)$ and $\mathrm{CD} 4+\mathrm{T}$ cells enhanced $\mathrm{T}$ cell activation, IL-2 expression, and CD25 levels. Besides, activation increased the capacity of $\mathrm{T}$ cells to synthesize endogenous amounts of $\mathrm{H}_{2} \mathrm{~S}$ through the increased expression of cystathionine $\gamma$-lyase and cystathionine $\beta$-synthase [35].

These results are reported in Table 5.

\section{Clinical trials and RCTs evaluating the beneficial effects of BT on immune response}

Most of the clinical studies and RCTs evaluating the immunological effects of thermal waters focused on musculoskeletal diseases. Bellometti et al. in 1997 [36] conducted a study enrolling a group of $22 \mathrm{OA}$ patients. The patients underwent 12 mud pack treatments and after the treatment an increase in insulin growth factor 1 (IGF-1) and a decrease of TNF- $\alpha$ in serum were observed. After mud pack therapy also, a decrease in serum levels of PGE2 and leukotriene (LTB4), was observed [37]. In patients with primary symptomatic bilateral knee OA, randomly assigned to receive a cycle of mud-bath therapy or to continue their standard therapy alone, in the group of mud-bath therapy, a significant increase of C-terminal cross-linked telopeptide type II collagen (CTX-II), perhaps due to an increase of cartilage turnover induced by thermal stress, was observed [38]. Ortega et al. [39] in 2017 evaluated the effects of a 10-day cycle of mud therapy in a group of patients with primary knee OA. After the cycle of mud therapy, serum concentrations of IL- $1 \beta$, TNF- $\alpha$, IL- 8 , IL-6, TGF- $\beta$, and extracellular heat-shock protein 72 (eHsp72) were markedly decreased and systemic levels of cortisol significantly increased.

Galvéz et al. [40] showed in patients with knee OA who underwent a cycle of BT with mud applications a reduction in the percentage of $\mathrm{CD} 4+\mathrm{T}$ regulatory cells and an enancement in CD8 $+\mathrm{T}$ regulatory cells, wich play a key role in regulating immune reactions, contolling inflammation and maintaining immune homeostasis. In addition, an increased neutrophil functional capacity was observed.

Tarner et al. [41] analyzed the effect of mild whole-body hyperthermia in ankylosing spondylitis (AS). Serum samples were taken to measure TNF- $\alpha$, IL- $1 \beta$ and IL-6. Hyperthermia caused a significant reduction of all cytokines by $40-50 \%$. A significant increase in transforming growth factor (TGF)- $\beta 1$ was found in AS patients treated with active exercises, hyperthermia and exposure to low doses of radon in a former mine (total and active) [42].

In fibromyalgia, female patients treated with BT five days per week for 3 weeks, mean PGE2 levels were higher compared to healthy control group and decreased after the treatment period. Also, IL-1 and LTB4 significantly decreased after the treatment. [43]

Eysteinsdoóttir et al. [44] investigated the effects of bathing in geothermal seawater in addition to the narrowband ultraviolet B (NB-UVB) therapy in patients suffering from psoriasis. Compared with healthy controls, psoriasis patients with active disease had significantly higher proportion of peripheral cutaneous lymphocyte-associated antigen (CLA) $+\mathrm{T}$ cells expressing $\mathrm{C}-\mathrm{C}$ motif chemokine receptor 10 (CCR10) and CD103 and T cells with both Th1/ Tc1 and Th17/Tc17 phenotypes. A reduction in circulating CLA + peripheral blood T cells and a decreased Th1/Th17 and Tc1/Tc17 inflammatory response were shown after BT and NB-UVB therapy.

The radioactive and thermal effects of radon hot spring were biochemically compared under a sauna room or hot spring conditions with a similar chemical component [45]. The radon and thermal therapy enhanced the antioxidation 


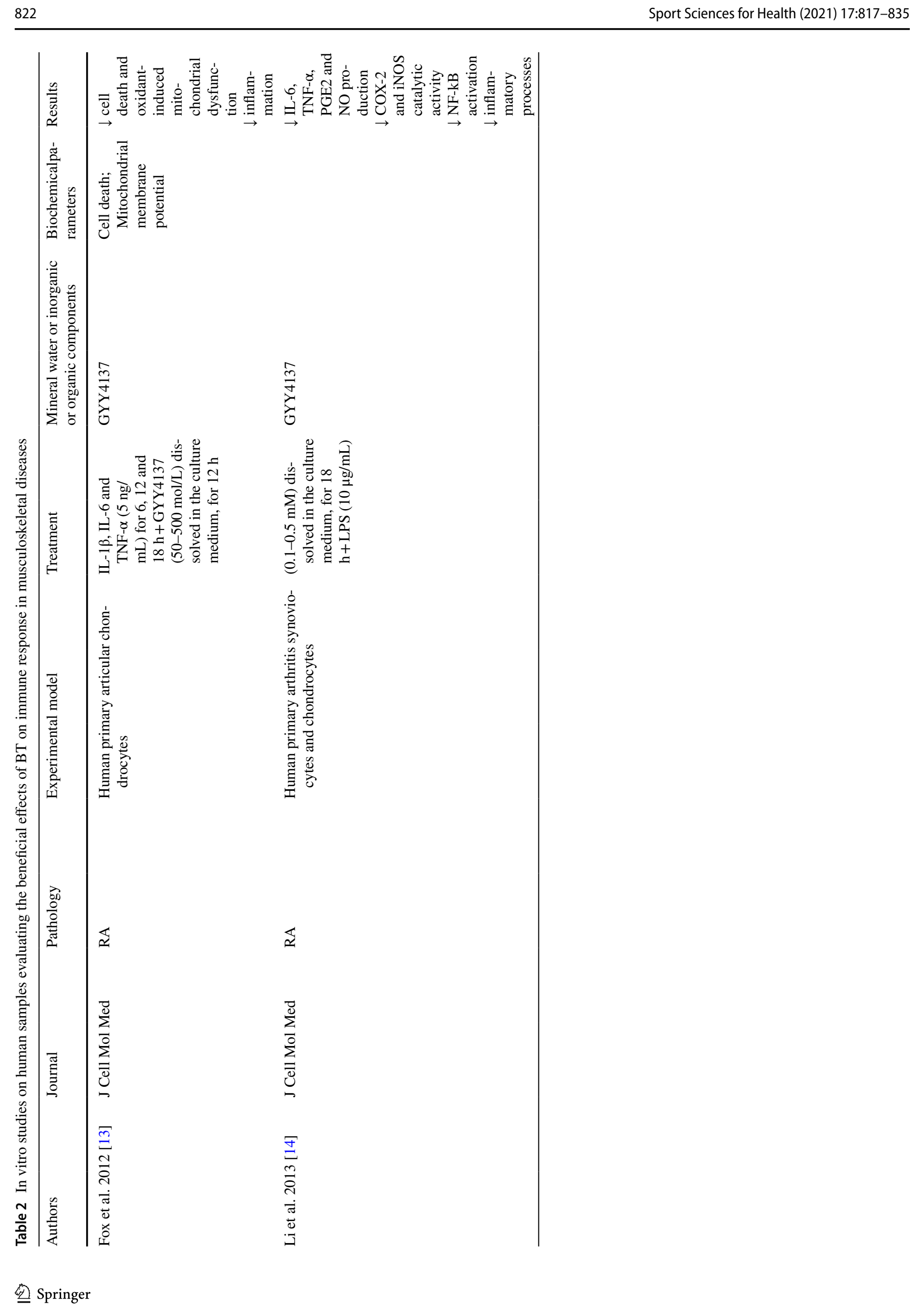




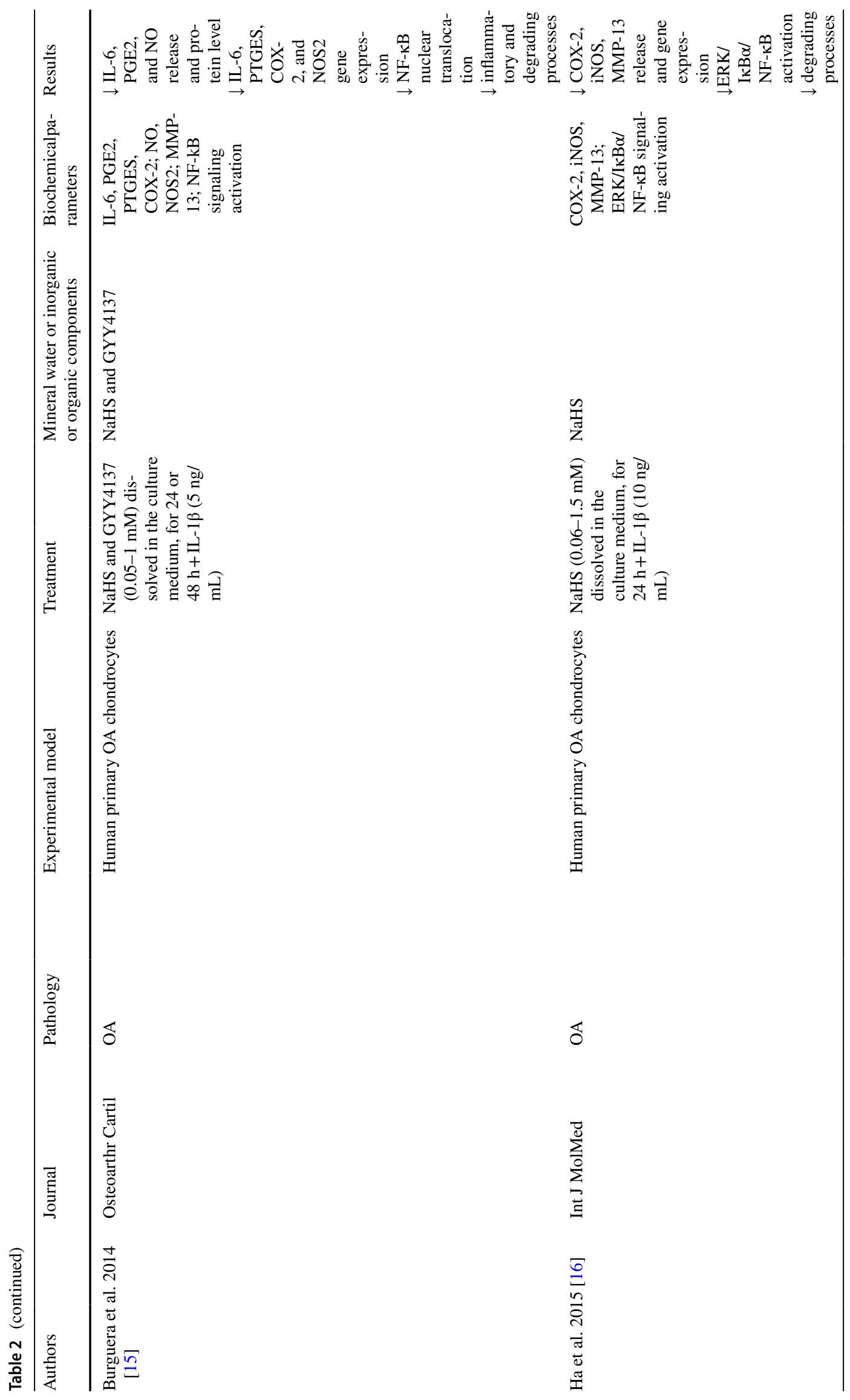




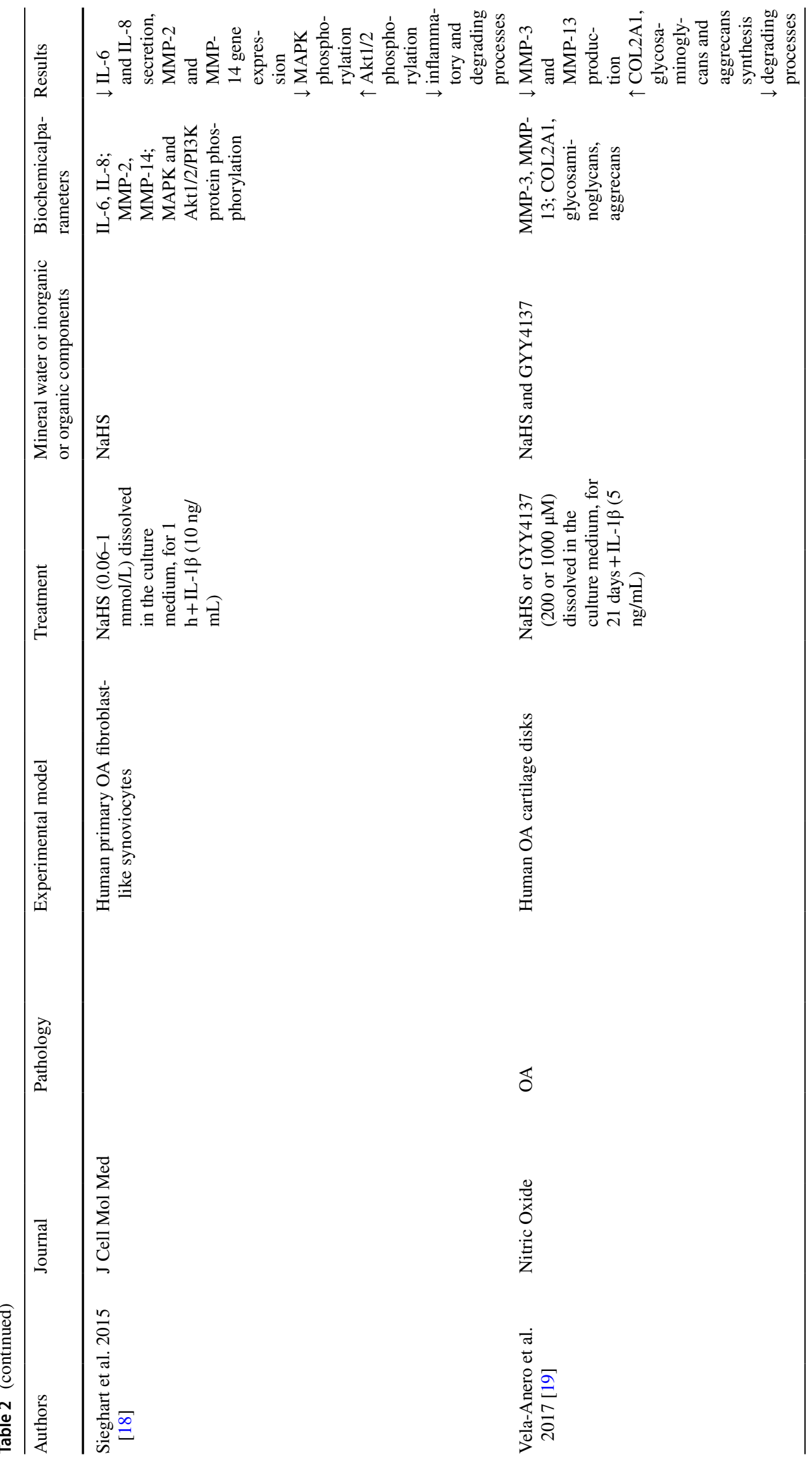




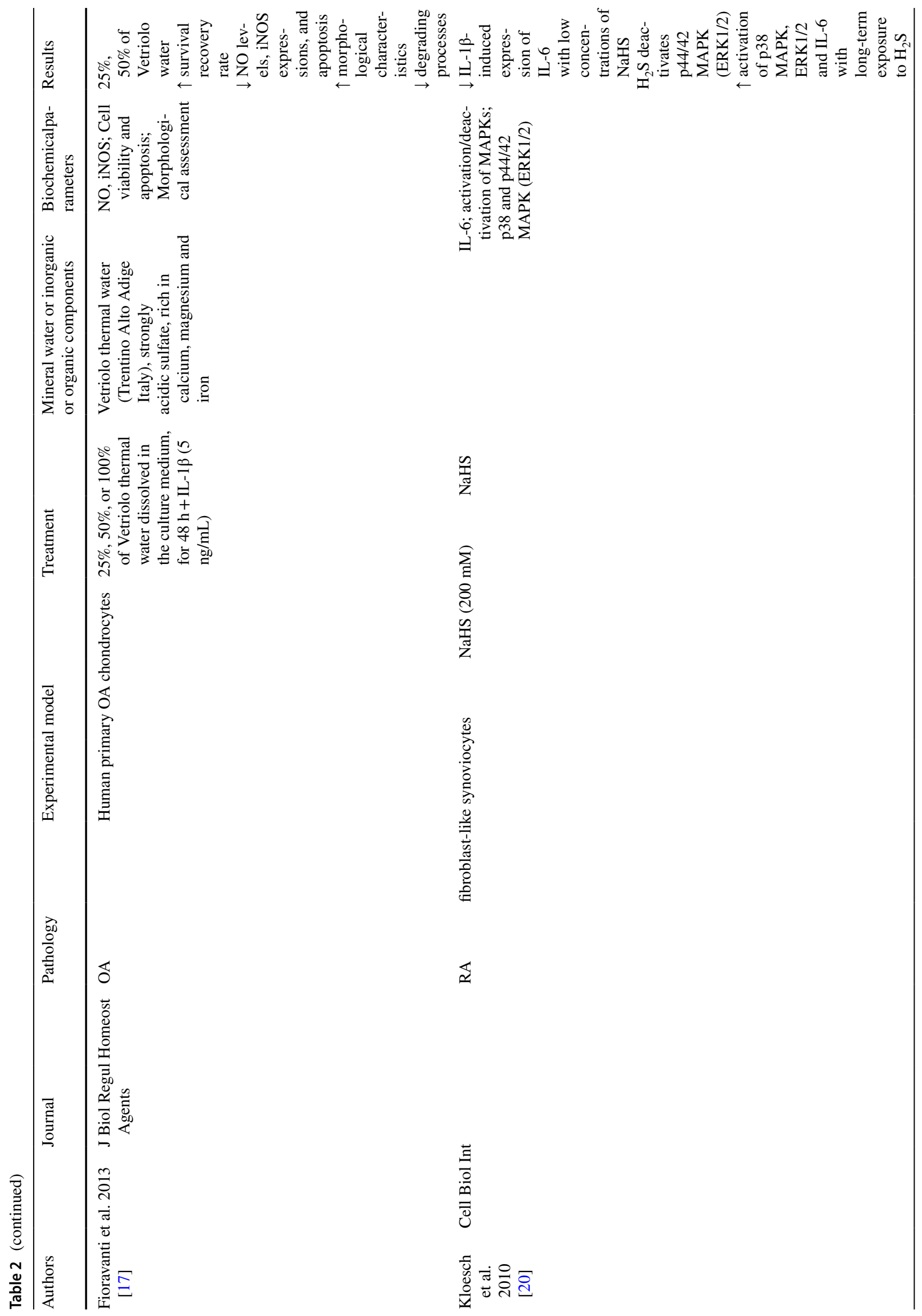




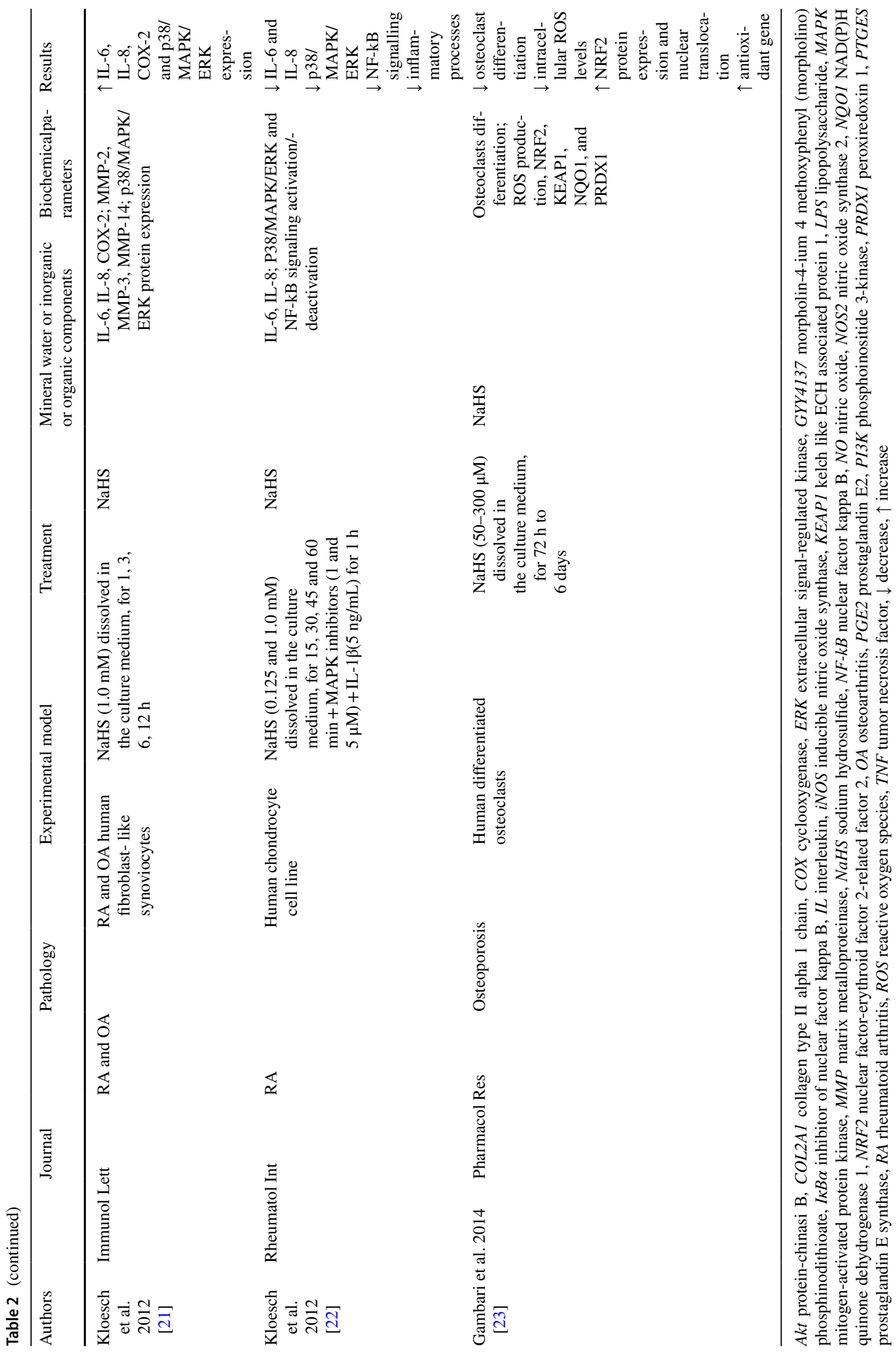




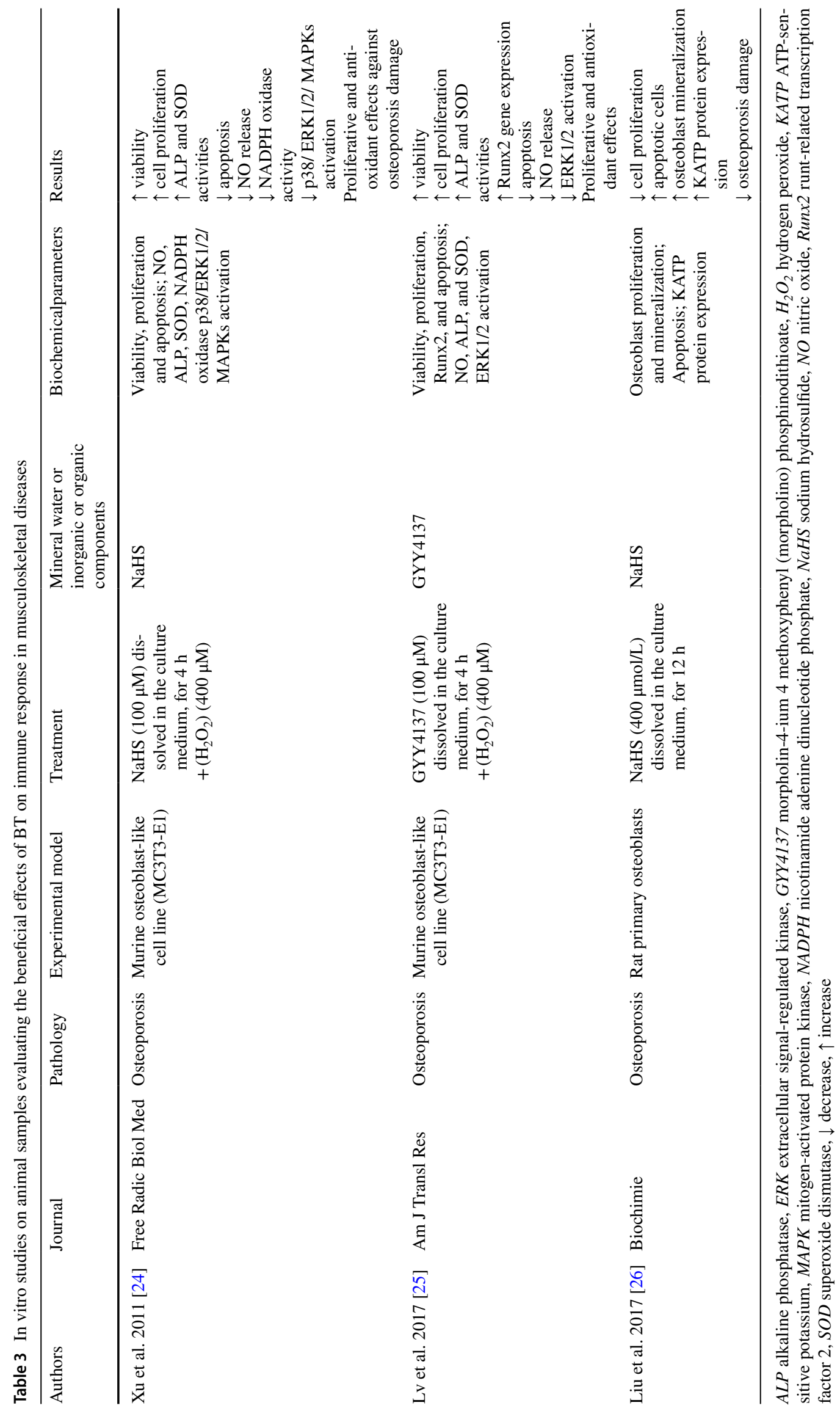




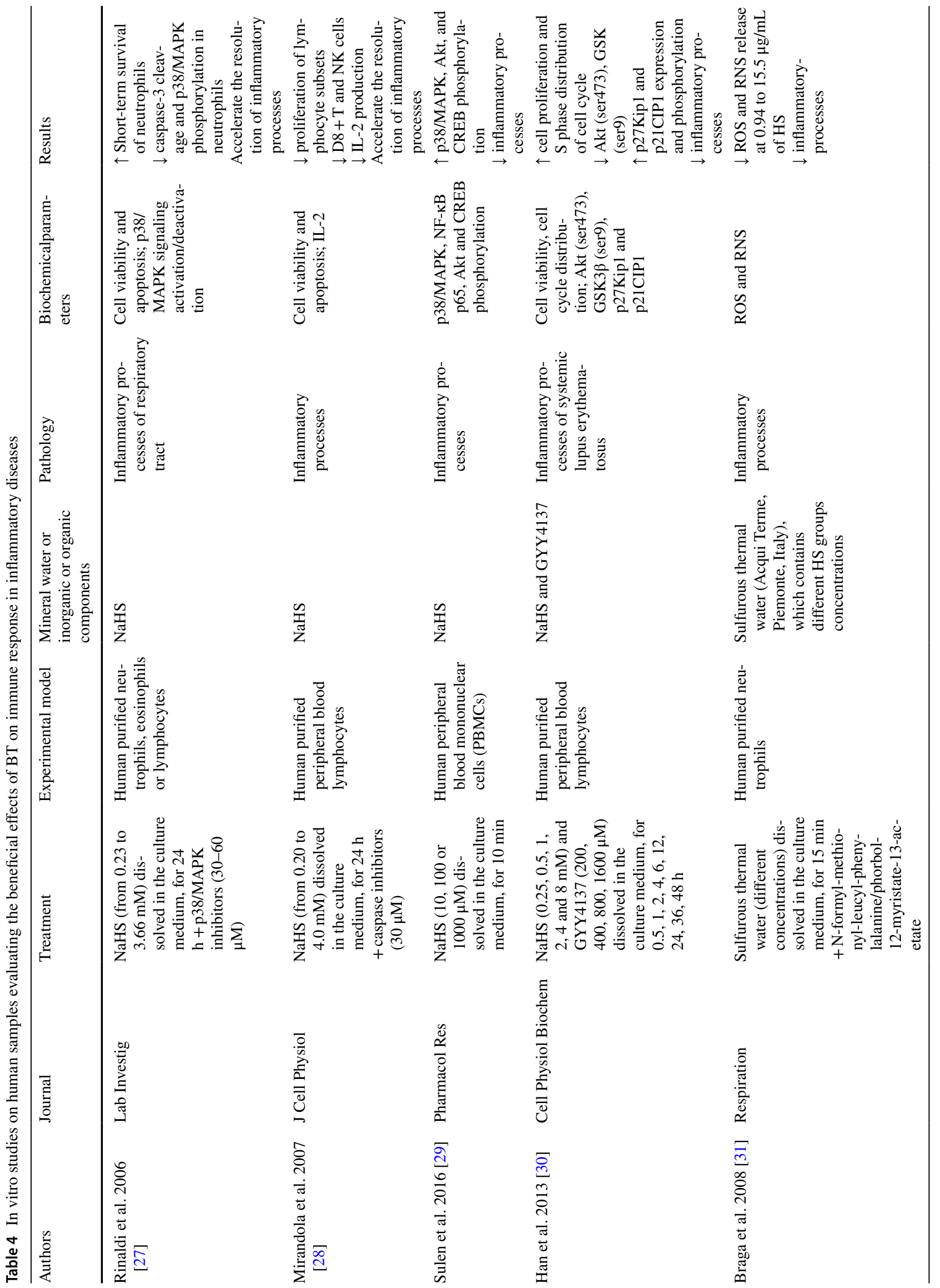


Sport Sciences for Health (2021) 17:817-835

829

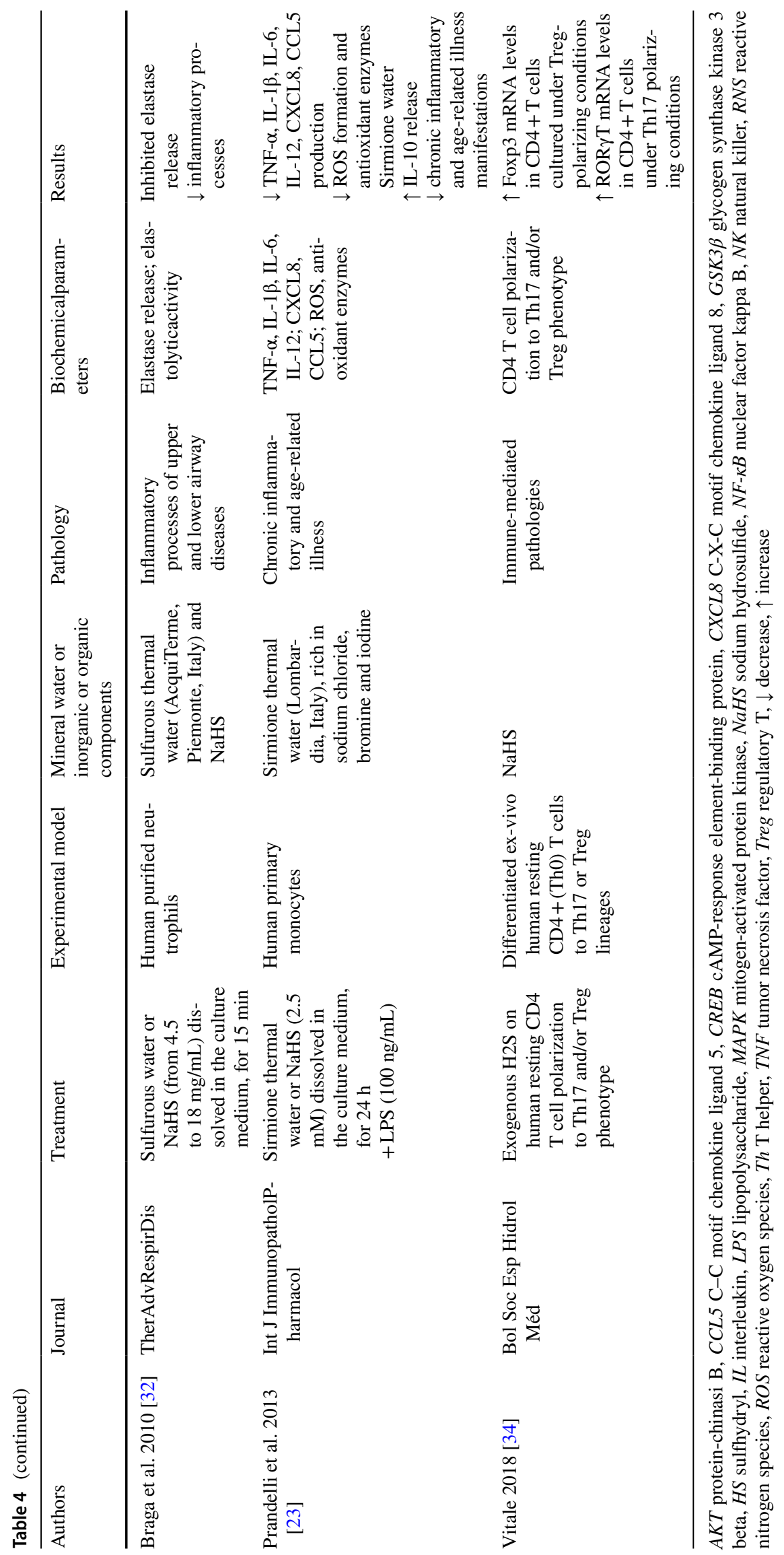

Springer 


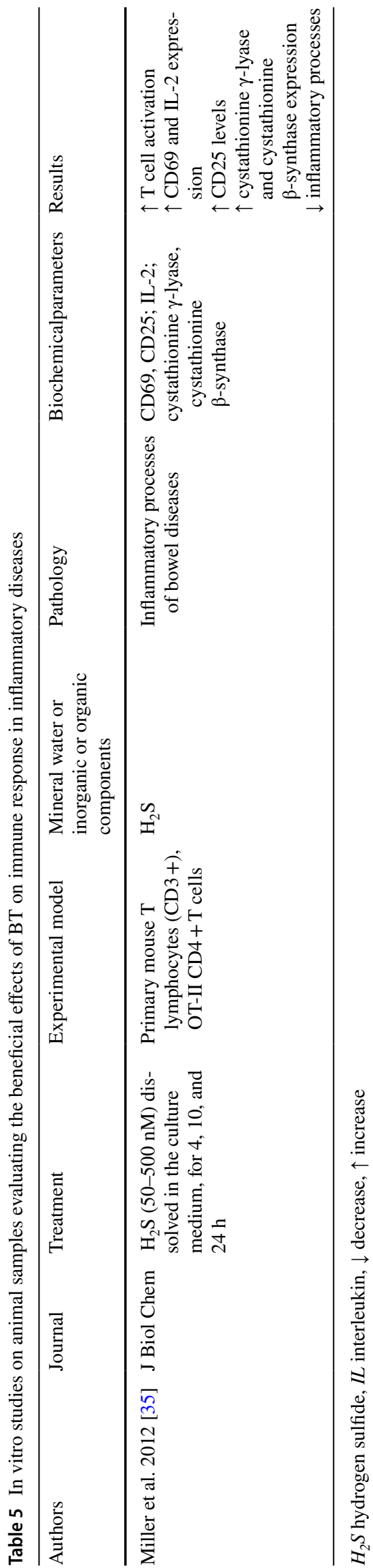

functions, such as the activities of superoxide dismutase and catalase, which inhibit lipid peroxidation and total cholesterol produced in the body, increased the percentage of CD4positive cells (marker of helper T cells) and decreased the percentage of CD8-positive cells (marker of killer T cells and suppressor $\mathrm{T}$ cells). Furthermore, the therapy increased the levels of alpha atrial natriuretic polypeptide, beta endorphin, adrenocorticotropic hormone, insulin and glucose6-phosphate dehydrogenase, and decreased the vasopression level. The results were larger in the radon group than in the thermal group, suggesting that radon therapy contributes more to the prevention of life-style-related diseases related to peroxidation reactions and immune suppression than thermal therapy.

All the treatment details and results of these studies are reported in Table 6 .

\section{Discussion}

In in vitro human samples, $\mathrm{H}_{2} \mathrm{~S}$ donors (NaHS and GYY4137) were demonstrated to exert anti-inflammatory and anti-angiogenic effects, confirming the beneficial properties of mineral water sulfur components on psoriatic lesions. $\mathrm{H}_{2} \mathrm{~S}$ sources seem to counteract the inflammatory processes both in arthritic fibroblast-like synoviocytes and chondrocytes, and in OA chondrocytes. All these findings provide new information about the anti-inflammatory, antioxidant, and anti-catabolic properties of $\mathrm{H}_{2} \mathrm{~S}$. In particular, $\mathrm{H}_{2} \mathrm{~S}$ seems to act as a chondroprotective agent by regulating important factors implicated in OA pathogenesis and progression, and counteracting IL- $1 \beta$ pro-inflammatory signals that lead to cartilage destruction. The capacity of $\mathrm{H}_{2} \mathrm{~S}$ donors to limit the oxidative stress damage was demonstrated also in cell lines of osteoblasts. Moreover, the sulfide compounds appear to regulate inflammation and immune response in human psoriatic keratinocytes and in purified human peripheral blood neutrophils, eosinophils and lymphocytes.

Even in the cohorts of patients suffering from OA, BT has demonstrated to have anti-inflammatory efficacy, modulating the cytokinic response and modifying the percentage of regulatory T cells in circulation. After BT and mud therapy, a reduction in serum levels of pro-inflammatory molecules, such as TNF- $\alpha$, IL-1 $\beta$, PGE2, LTB4 and C-reactive protein, and an increase in anti-inflammatory molecules such as the IGF-1 growth factor have been shown. Furthermore, a decrease in the concentration of MMP, involved in cartilage degradation, has been reported after mud therapy in OA patients, maybe as a consequence of the reduction in pro-inflammatory mediators that promote MMP secretion. BT contributes also to a modification in cellular immune response: after mud therapy, OA patients presented increased neutrophils' levels and functional capacity [46]. 


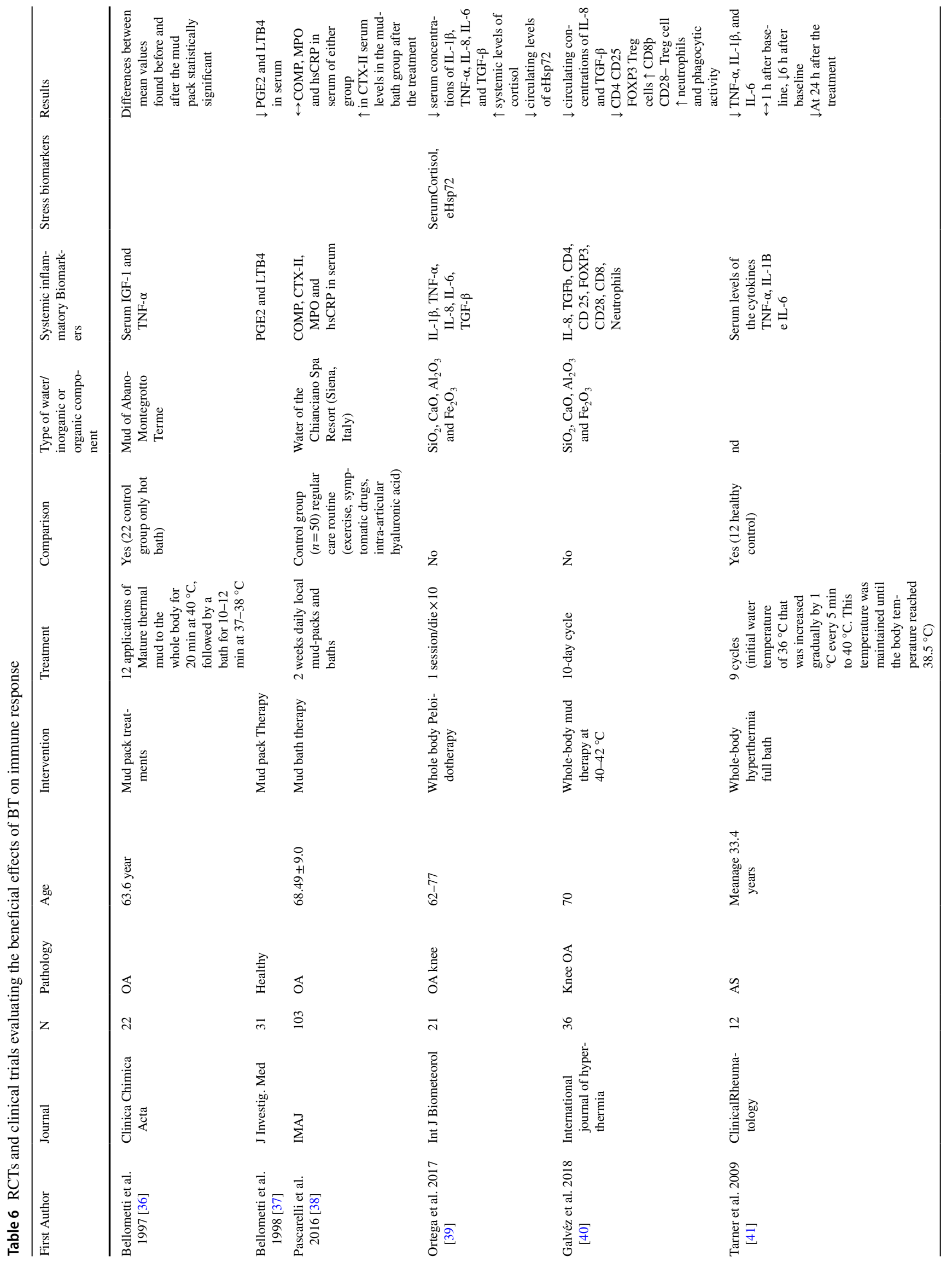




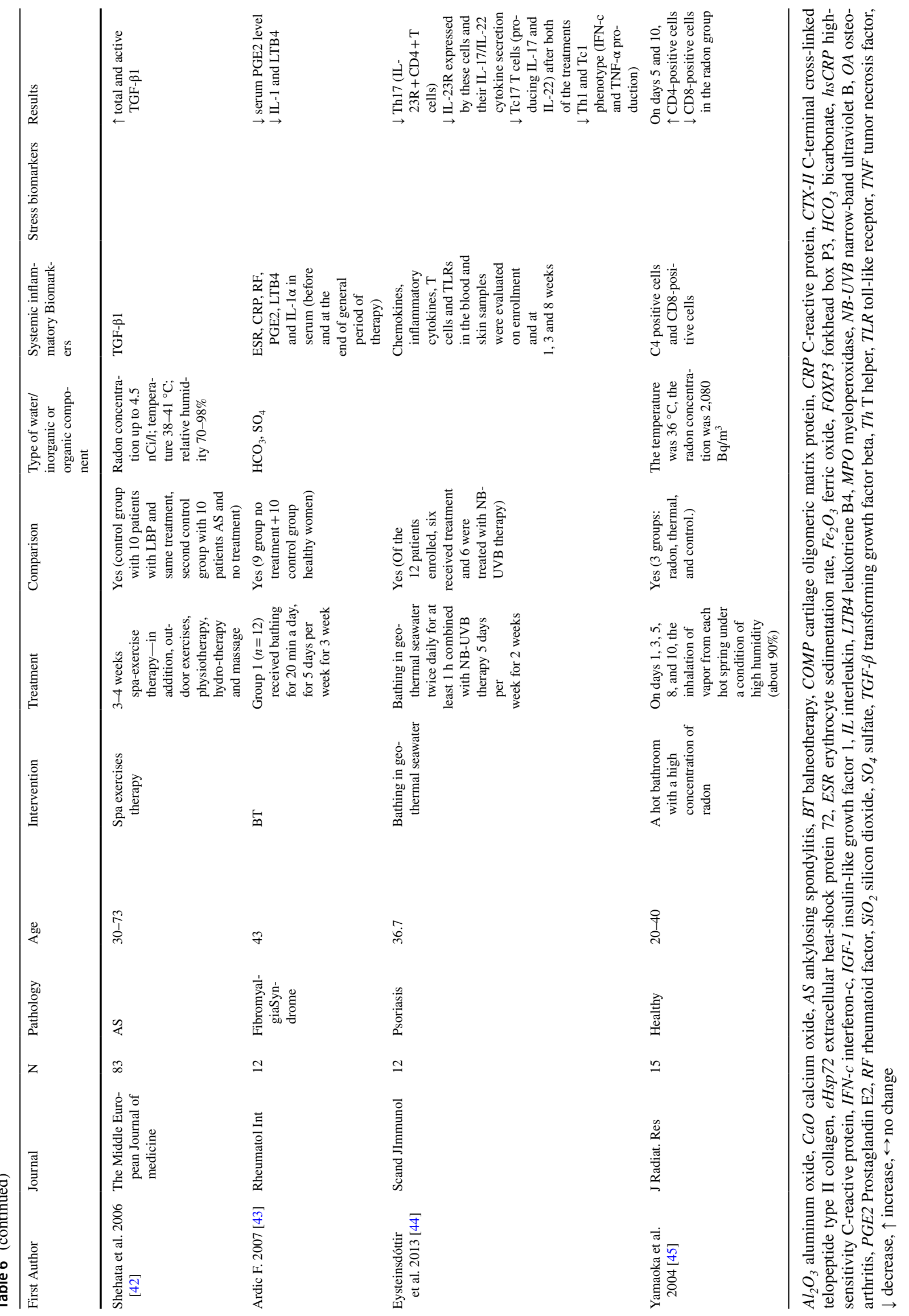


Also in patients with fibromyalgia or AS, BT can influence the inflammatory mediators. In particular, in AS patients, whole-body hyperthermia and speleotherapy resulted in changes of the pro-inflammatory cytokine network.

Finally, BT should have also an anti-inflammatory role on healthy subjects.

Due to the heterogeneity of composition characteristics of the natural mineral water or mud used and to the different sample size and performed protocols considered in the clinical trials, it is not possible to define with certainty the BT effects on the immune system. However, the results showed some beneficial effects that can to some degree positively modify the inflammatory response.

\section{Conclusion}

In conclusion, studies on in vitro samples could open the way to the scientific progress to develop further clinical studies and RCTs evaluating the effects of BT on the immune system, to exploit BT in real life for preventive, curative and rehabilitation treatments [47].

Funding Open access funding provided by Università degli Studi di Padova within the CRUI-CARE Agreement.

\section{Declarations}

Conflict of interest The authors declare that they have no conflict of interest.

Ethical approval Not applicable.

Informed consent Not applicable.

Open Access This article is licensed under a Creative Commons Attribution 4.0 International License, which permits use, sharing, adaptation, distribution and reproduction in any medium or format, as long as you give appropriate credit to the original author(s) and the source, provide a link to the Creative Commons licence, and indicate if changes were made. The images or other third party material in this article are included in the article's Creative Commons licence, unless indicated otherwise in a credit line to the material. If material is not included in the article's Creative Commons licence and your intended use is not permitted by statutory regulation or exceeds the permitted use, you will need to obtain permission directly from the copyright holder. To view a copy of this licence, visit http://creativecommons.org/licenses/by/4.0/.

\section{References}

1. Gutenbrunner C, Bender T, Cantista P, Karagülle Z (2010) A proposal for a worldwide definition of health resort medicine, balneology, medical hydrology and climatology. Int J Biometeorol 54(5):495-507. https://doi.org/10.1007/s00484-010-0321-5
2. Masiero S, Litwocenko S, Agostini F (2020) On behalf section of Rehabilitation in Environmental Thermal for Italian Society of Physical Medicine and Rehabilitation. Rehabilitation in an Italian thermal setting: a new therapeutic strategy for patients with musculoskeletal disability-the results of an Italian survey. Int J Biometeorol. 64(6):951-954

3. Masiero S, Maccarone MC, Magro G (2020) Balneotherapy and human immune function in the era of COVID-19. Int J Biometeorol 64:1433-1434. https://doi.org/10.1007/s00484-020-01914-z

4. Maccarone MC, Magro G, Solimene U, Masiero S (2020) The effects of balneotherapy on human immune function: should baths and mud applications have a role during Covid-19 pandemic? Bull Rehabil Med 97(3):22-24

5. Marzano AV, Derlino F, Berti EF (2018) Pathogenesis of psoriasis: focus on autoinflammation. Dermatopathology (Basel) 5(1):14-15. https://doi.org/10.1159/000486304

6. Gobbi G, Ricci F, Malinverno C, Carubbi C, Pambianco M, Gd P, Vitale M, Mirandola P (2009) Hydrogensulfide impairs keratinocyte cell growth and adhesion inhibiting mitogen-activated proteinkinase signaling. Lab Investig 89(9):994-1006. https://doi.org/ 10.1038/labinvest.2009.61

7. Mirandola P, Gobbi G, Micheloni C, Vaccarezza M, Di Marcantonio D, Ruscitti F, de Panfilis G, Vitale M (2011) Hydrogen sulfide inhibits IL-8 expression in human keratinocytes via MAP kinasesignaling. Lab Investig 91(8):1188-1194. https://doi.org/10.1038/ labinvest.2011.76

8. Chiarini A, Dal Pra I, Pacchiana R, Menapace L, Zumiani G, Zanoni M, Armato U (2006) Comano (Trentino) thermal water interferes with the expression and secretion of vascular endothelial growth factor-A protein isoforms by cultured human psoriatic keratinocytes: a potential mechanism of its anti-psoriatic action. Int J Mol Med 18(1):17-25

9. Chiarini A, Dal Pra I, Pacchiana R, Zumiani G, Zanoni M, Armato U (2006) Comano (Trentino) thermal water interferes with interleukin-6 production and secretion and with cytokeratin-16 expression by cultured human psoriatic keratinocytes: further potential mechanisms of its anti-psoriatic action. Int J Mol Med 18(6):1073-1079

10. Dal Pra I, Chiarini A, Pacchiana R, Zumiani G, Zanoni M, Armato U (2007) Comano (Trentino) thermal water interferes with tumour necrosis factor-alpha expression and interleukin- 8 production and secretion by cultured human psoriatic keratinocytes: yet other mechanisms of its anti-psoriatic action. Int J Mol Med 19(3):373-379

11. Karagülle MZ, Karagülle M, Kılıç S, Sevinç H, Dündar C, Türkoğlu M (2018) In vitro evaluation of natural thermal mineral waters in human keratinocyte cells: a preliminary study. Int J Biometeorol 62(9):1657-1661. https://doi.org/10.1007/ s00484-018-1565-8

12. Lee HP, Choi YJ, Cho KA, Woo SY, Yun ST, Lee JT, Kim HJ, Lee KH, Kim JW (2012) Effect of spa spring water on cytokine expression in human keratinocyte $\mathrm{HaCaT}$ cells and on differentiation of CD4(+) T cells. Ann Dermatol 24(3):324-336. https://doi. org/10.5021/ad.2012.24.3.324

13. Fox B, Schantz JT, Haigh R, Wood ME, Moore PK, Viner N, Spencer JP, Winyard PG, Whiteman M (2012) Inducible hydrogen sulfide synthesis in chondrocytes and mesenchymal progenitor cells: is $\mathrm{H} 2 \mathrm{~S}$ a novel cytoprotective mediator in the inflamed joint? J Cell Mol Med 16(4):896-910. https://doi.org/10.1111/j.15824934.2011.01357.x

14. Li L, Fox B, Keeble J, Salto-Tellez M, Winyard PG, Wood ME, Moore PK, Whiteman M (2013) The complex effects of the slowreleasing hydrogen sulfide donor GYY4137 in a model of acute joint inflammation and in human cartilage cells. J Cell Mol Med 17(3):365-376. https://doi.org/10.1111/jcmm.12016 
15. Burguera EF, Vela-Anero A, Magalhães J, Meijide-Faílde R, Blanco FJ (2014) Effect of hydrogen sulfide sources on inflammation and catabolic markers on interleukin $1 \beta$-stimulated human articular chondrocytes. OsteoarthrCartil 22(7):1026-1035. https:// doi.org/10.1016/j.joca.2014.04.031

16. Ha C, Tian S, Sun K, Wang D, Lv J, Wang Y (2015) Hydrogen sulfide attenuates IL-1 $\beta$-induced inflammatory signaling and dysfunction of osteoarthritic chondrocytes. Int J Mol Med 35(6):1657-1666. https://doi.org/10.3892/ijmm.2015.2183

17. Fioravanti A, Lamboglia A, Pascarelli NA, Cheleschi S, Manica P, Galeazzi M, Collodel G (2013) Thermal water of Vetriolo, Trentino, inhibits the negative effect of interleukin 1ßonnitricoxide production and apoptosis in human osteoarthriticchondrocyte. J BiolRegulHomeost Agents 27(3):891-902

18. Sieghart D, Liszt M, Wanivenhaus A, Bröll H, Kiener H, Klösch B, Steiner G (2015) Hydrogen sulphide decreases IL-1 $\beta$-induced activation of fibroblast-like synoviocytes from patients with osteoarthritis. J Cell Mol Med 19(1):187-197. https://doi.org/10.1111/ jcmm. 12405

19. Vela-Anero Á, Hermida-Gómez T, Gato-Calvo L, VaamondeGarcía C, Díaz-Prado S, Meijide-Faílde R, Blanco FJ, Burguera EF (2017) Long-term effects of hydrogen sulfide on the anaboliccatabolic balance of articular cartilage in vitro. Nitric Oxide 70:42-50. https://doi.org/10.1016/j.niox.2017.08.004

20. Kloesch B, Liszt M, Broell J (2010) H2S transiently blocks IL-6 expression in rheumatoid arthritic fibroblast-like synoviocytes and deactivates p44/42 mitogen-activated protein kinase. Cell Biol Int 34(5):477-484. https://doi.org/10.1042/CBI20090436

21. Kloesch B, Liszt M, Krehan D, Broell J, Kiener H, Steiner G (2012) High concentrations of hydrogen sulphide elevate the expression of a series of pro-inflammatory genes in fibroblast-like synoviocytes derived from rheumatoid and osteoarthritis patients. Immunol Lett 141(2):197-203. https://doi.org/10.1016/j.imlet. 2011.10.004

22. Kloesch B, Liszt M, Steiner G, Bröll J (2012) Inhibitors of p38 and ERK1/2 MAPkinase and hydrogen sulphide block constitutive and IL-1 $\beta$-induced IL- 6 and IL-8 expression in the human chondrocyte cell line C-28/I2. Rheumatol Int 32(3):729-736. https:// doi.org/10.1007/s00296-010-1682-0

23. Gambari L, Lisignoli G, Cattini L, Manferdini C, Facchini A, Grassi F (2014) Sodium hydrosulfide inhibits the differentiation of osteoclast progenitor cells via NRF2-dependent mechanism. Pharmacol Res 87:99-112. https://doi.org/10.1016/j.phrs.2014. 06.014

24. Xu ZS, Wang XY, Xiao DM, Hu LF, Lu M, Wu ZY, Bian JS (2011) Hydrogen sulfide protects MC3T3-E1 osteoblastic cells against $\mathrm{H} 2 \mathrm{O} 2$-induced oxidative damage-implications for the treatment of osteoporosis. Free Radic Biol Med 50(10):13141323. https://doi.org/10.1016/j.freeradbiomed.2011.02.016

25. Lv M, Liu Y, Xiao TH, Jiang W, Lin BW, Zhang XM, Lin YM, Xu ZS (2017) GYY4137 stimulates osteoblastic cell proliferation and differentiation via an ERK1/2-dependent anti-oxidant mechanism. Am J Transl Res 9(3):1183-1192

26. Liu Y, Liu J, Li X, Wang F, Xu X, Wang C (2017) Exogenous $\mathrm{H} 2 \mathrm{~S}$ prevents high glucose-induced damage to osteoblasts through regulation of KATP channels. Biochimie 137:151-157. https:// doi.org/10.1016/j.biochi.2017.03.009

27. Rinaldi L, Gobbi G, Pambianco M, Micheloni C, Mirandola P, Vitale M (2006) Hydrogen sulfide prevents apoptosis of human PMN via inhibition of p38 and caspase3. Lab Investig 86(4):391397. https://doi.org/10.1038/labinvest.3700391

28. Mirandola P, Gobbi G, Sponzilli I, Pambianco M, Malinverno C, Cacchioli A, De Panfilis G, Vitale M (2007) Exogenous hydrogen sulfide induces functional inhibition and cell death of cytotoxic lymphocytes subsets. J Cell Physiol 213(3):826-833. https://doi. org/10.1002/jcp.21151
29. Sulen A, Gullaksen SE, Bader L, McClymont DW, Skavland J, Gavasso S, Gjertsen BT (2016) Signaling effects of sodium hydrosulfide in healthy donor peripheral blood mononuclear cells. Pharmacol Res 113(Pt A):216-227. https://doi.org/10.1016/j.phrs. 2016.08.018

30. Han Y, Zeng F, Tan G, Yang C, Tang H, Luo Y, Feng J, Xiong H, Guo Q (2013) Hydrogen sulfide inhibits abnormal proliferation of lymphocytes via AKT/GSK3 $\beta$ signal pathway in systemic lupus erythematosus patients. Cell Physiol Biochem 31(6):795-804. https://doi.org/10.1159/000350097

31. Braga PC, Sambataro G, Dal Sasso M, Culici M, Alfieri M, Nappi G (2008) Antioxidant effect of sulphurous thermal water on human neutrophil bursts: chemiluminescence evaluation. Respiration 75(2): 193-201

32. Braga PC, Dal Sasso M, Culici M, Spallino A, Marabini L, Bianchi T, Nappi G (2010) Effects of sulphurous water on human neutrophilelastase release. Ther Adv Respir Dis 4(6):333-340. https://doi.org/10.1177/1753465810376783

33. Prandelli C, Parola C, Buizza L, Delbarba A, Marziano M, Salvi V, Zacchi V, Memo M, Sozzani S, Calza S, Uberti D, Bosisio D (2013) Sulphurousthermal water increases the release of the antiinflammatory cytokine IL-10 and modulates antioxidant enzyme activity. Int J Immunopathol Pharmacol 26(3):633-646. https:// doi.org/10.1177/039463201302600307

34. Vitale M (2018) Sulphur balneotherapy and patient's immunity: H2S effects on human CD4+ T cell polarization to Th17 and Treg phenotype. Bol Soc Esp Hidrol Méd 33(1):68-69

35. Miller TW, Wang EA, Gould S, Stein EV, Kaur S, Lim L, Amarnath S, Fowler DH, Roberts DD (2012) Hydrogen sulfide is an endogenous potentiator of $\mathrm{T}$ cell activation. $\mathrm{J}$ Biol Chem 287(6):4211-4221. https://doi.org/10.1074/jbc.M111.307819

36. Bellometti S, Cecchettin M, Galzigna L (1997) Mud pack therapy in osteoarthritis. Changes in serum levels of chondrocyte markers. Clin Chim Acta 268(1-2):101-106. https://doi.org/10.1016/ s0009-8981(97)00171-x

37. Bellometti S, Galzigna L (1998) Serum levels of a prostaglandin and a leukotriene after thermal mud pack therapy. J InvestigMed 46(4):140-145

38. Pascarelli NA, Cheleschi S, Bacaro G, Guidelli GM, Galeazzi M, Fioravanti A (2016) Effect of mud-bath therapy on serum biomarkers in patients with knee osteoarthritis: results from a randomized controlled trial. Isr Med Assoc J 18(3-4):232-237

39. Ortega E, Gálvez I, Hinchado MD, Guerrero J, Martín-Cordero L, Torres-Piles S (2017) Anti-inflammatory effect as a mechanism of effectiveness underlying the clinical benefits of pelotherapy in osteoarthritis patients: regulation of the altered inflammatory and stress feedback response. Int J Biometeorol 61(10):1777-1785. https://doi.org/10.1007/s00484-017-1361-x

40. Gálvez I, Torres-Piles S, Ortega E (2018) Innate/inflammatory bioregulation and clinical effectiveness of whole- body hyperthermia (balneotherapy) in elderly patients with osteoarthritis. Int J Hyperth 35(1):340-347. https://doi.org/10.1080/02656736.2018. 1502896

41. Tarner IH, Müller-Ladner U, Uhlemann C, Lange U (2009) The effect of mild whole-body hyperthermia on systemic levels of TNF-alpha, IL-1beta, and IL-6 in patients with ankylosing spondylitis. Clin Rheumatol 28(4):397-402. https://doi.org/10.1007/ s10067-008-1059-x

42. Shehata M, Schwarzmeier J, Hilgarth M, Demirtas D, Richter D, Hubmann R, Boeck P, Leiner G, Falkenbach A (2006) Effect of combined spa-exercise therapy on circulating TGF- $\beta 1$ levels in patients with ankylosing spondylitis. Wienerklinische Wochenschrift 118:266-272. https://doi.org/10.1007/s00508-006-0560-y

43. Ardiç F, Ozgen M, Aybek H, Rota S, Cubukçu D, Gökgöz A (2007) Effects of balneotherapy on serum IL-1, PGE2 and LTB4 
levels in fibromyalgia patients. Rheumatol Int 27(5):441-446. https://doi.org/10.1007/s00296-006-0237-x

44. Eysteinsdóttir JH, Sigurgeirsson B, Ólafsson JH, Fridriksson Th, Agnarsson BA, Davíðsson S, Valdimarsson H, Lúðvíksson BR (2013) The role of Th17/Tc17 peripheral blood T cells in psoriasis and their positive therapeutic response. Scand J Immunol 78(6):529-537. https://doi.org/10.1111/sji.12114

45. Yamaoka K, Mitsunobu F, Hanamoto K, Shibuya K, Mori S, Tanizaki Y, Sugita K (2004) Biochemical comparison between radon effects and thermal effects on humans in radon hot spring therapy. J Radiat Res 45(1):83-88. https://doi.org/10.1269/jrr.45.83

46. Gálvez I, Torres-Piles S, Ortega-Rincón E (2018) Balneotherapy, immune system, and stress response: a hormetic strategy? Int J Mol Sci 19(6):1687. https://doi.org/10.3390/ijms19061687
47. Masiero S (2008) Thermal rehabilitation and osteoarticular diseases of the elderly. Aging Clin Exp Res 20:189-194. https://doi. org/10.1007/BF03324772

Publisher's Note Springer Nature remains neutral with regard to jurisdictional claims in published maps and institutional affiliations. 